\title{
Numerical study of the influence of water evaporation on radiofrequency ablation
}

\author{
Qing Zhu', Yuanyuan Shen ${ }^{2}$, Aili Zhang ${ }^{1 *}$ and Lisa $X \mathrm{Xu}^{1^{*}}$
}

\author{
* Correspondence: zhangaili@sjtu. \\ edu.cn; lisaxu@sjtu.edu.cn \\ ${ }^{1}$ State Key Laboratory of Oncogenes \\ and Related Genes, School of \\ Biomedical Engineering, Med-X \\ Research Institute, Shanghai Jiao \\ Tong University, Shanghai, China \\ Full list of author information is \\ available at the end of the article
}

\begin{abstract}
Background: Radiofrequency ablation is a promising minimal invasive treatment for tumor. However, water loss due to evaporation has been a major issue blocking further RF energy transmission and correspondently eliminating the therapeutic outcome of the treatment.

Method: A 2D symmetric cylindrical mathematical model coupling the transport of the electrical current, heat, and the evaporation process in the tissue, has been developed to simulate the treatment process and investigate the influence of the excessive evaporation of the water on the treatment.

Results: Our results show that the largest specific absorption rate $\left(Q_{S A R}\right)$ occurs at the edge of the circular surface of the electrode. When excessive evaporation takes place, the water dehydration rate in this region is the highest, and after a certain time, the dehydrated tissue blocks the electrical energy transmission in the radial direction. It is found that there is an interval as long as $65 \mathrm{~s}$ between the beginning of the evaporation and the increase of the tissue impedance. The model is further used to investigate whether purposely terminating the treatment for a while allowing diffusion of the liquid water into the evaporated region would help. Results show it has no obvious improvement enlarging the treatment volume. Treatment with the cooled-tip electrode is also studied. It is found that the cooling conditions of the inside agent greatly affect the water loss pattern. When the convection coefficient of the cooling agent increases, excessive evaporation will start from near the central axis of the tissue cylinder instead of the edge of the electrode, and the coagulation volume obviously enlarges before a sudden increase of the impedance. It is also found that a higher convection coefficient will extend the treatment time. Though the sudden increase of the tissue impedance could be delayed by a larger convection coefficient; the rate of the impedance increase is also more dramatic compared to the case with smaller convection coefficient.
\end{abstract}

Conclusion: The mathematical model simulates the water evaporation and diffusion during radiofrequency ablation and may be used for better clinical design of radiofrequency equipment and treatment protocol planning.

Keywords: Radiofrequency ablation, Water evaporation, Water diffusion, Mathematical model

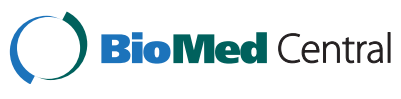

(C) 2013 Zhu et al.; licensee BioMed Central Ltd. This is an Open Access article distributed under the terms of the Creative Commons Attribution License (http://creativecommons.org/licenses/by/2.0), which permits unrestricted use, distribution, and reproduction in any medium, provided the original work is properly cited. The Creative Commons Public Domain Dedication waiver (http:// creativecommons.org/publicdomain/zero/1.0/) applies to the data made available in this article, unless otherwise stated. 


\section{Background}

Radiofrequency ablation (RFA) is one of the promising therapeutic procedures of primary and secondary malignant tumor due to its minimal invasiveness, less side-effect and immunology stimulation as compared with other treatment modalities [1,2]. The high frequency alternating electrical current forces agitation of the ions in the tissue, resulting in frictional heat of the tissue and correspondent abrupt increase of temperature. Previous studies show that, when the local temperature reaches the boiling temperature of water $100^{\circ} \mathrm{C}$, excessive evaporation takes place and increases the tissue impedance [3]. The roll-off has been a major obstacle for its application [4], especially for tumors larger than $3 \mathrm{~cm}$ [5-8]. Studies have been focused on improving therapeutic effect of RFA, either through better design of the device (for example, shape/geometry of electrodes, cooled-tip electrode) $[9,10]$, or optimizing the RF treatment protocols [11,12].

Multiple probes, wet electrode and cooled-tip electrode are techniques proposed to enlarge the lesion size [13-16]. These designs have been proven to be able to improve the therapeutic outcome, however a better design and planning of the treatment protocols is still needed for clinical applications of RF. When multiple probes create enlarged coagulation volume, there may exist survived tumor cells in the intermediate region of the multiple lesions $[15,16]$. Design of the wet electrode enables perfusion of the hypertonic saline solution into the tumor region with uncontrollable and irregular enlarged treatment area $[17,18]$. Design of the cooled-tip electrodes allows circulation of the cooling agents inside the electrode, which helps lower the temperature on the contact surface, thus slows down local water loss rate, and eventually increases the coagulation volume up to $50 \%$ [19]. However there also exists regions with evaporation which blocks the RF energy transportation [20,21]. The existence of the dehydration of the tissue not only leads to the final formation of charring and decreases the electrical conductivity of the tissue, it also adsorbs large quantity of energy. Understanding how the evaporation process influences the transportation of the electrical currents [9] and thus adsorption of the energy will be the key issue to be able to further optimize the treatment protocols.

Mathematical modeling has been an efficient and low cost modality in both design and treatment planning [22]. Models have been developed to simulate the temperature distributions of tissue during the treatment [4,23-26]. The complexity of the tumor composition, the influence of heterogeneous electrical conductivity, thermal conductivity, blood perfusion rate, and the specific distribution of blood vessels on the results have been studied [27-35].

However, most of the models have skipped the period when the excessive evaporation taking place during their simulation. Ai et al. [36] have incorporated the latent heat of evaporation into the specific heat capacity of the tissue in the bioheat transfer equation but diffusion of the water has been neglected. Yang et al. have proposed an empirical equation considering the influence of the evaporation process [37]. The dependence of the liver water content has been measured and a function describing this dependence established based on the experimental findings. The evaporation heat is further determined from the decreasing rate of liquid water fraction, and added as the heat sink in the heat transfer equation [38]. Both of these two models have ignored the influence of water loss on the electrical field and heat transfer as well. Patz et al. [39,40] has modeled the process of gas bubbles emerging, transportation, and merging with each other during the RF treatment. In their model, as soon as the tissue reached 
the boiling temperature, evaporation takes place, and an interface is immediately formed separating the gas region and the liquid region, which is inconsistent with Haemmerich's experiment findings [38].

In this study, a numerical model is developed investigating transportation of the electrical currents and heat inside the tissue during RF heating. Local boiling phenomena (evaporation) and diffusion of the water are both considered. These processes are coupled together. It is expected to help accurately predict deposition of RF energy before or after carbonization, and thus for effective prevention as needed. Also numerically studied is simulation of the treatment using different treatment protocols with the cooled-tip electrode.

\section{Theoretical modeling}

The electrodes of RFA used in this model are similar to those as described previously [41]. The geometry of the tissue and the electrode are illustrated in Figure 1. The treating surface of the electrode is a $10 \mathrm{~mm}$ diameter circle. The grounding pad is placed at the bottom of tissue. The tissue is assumed to be a symmetric cylinder with a diameter of $40 \mathrm{~mm}$ and a height of $40 \mathrm{~mm}$, which is estimated from a typical Wistar mouse's height and the width. And the tissue is assumed to be homogenous. Treating face of the electrode closely contacts the upper surface of tissue. The tissue and the electrode are assumed to be axially symmetric cylinders, thus only changes in the axial and radial directions are considered. So it is simplified to a 2-D model, and cross-section of electrode and tissue is studied.

The RF frequency used is $460 \mathrm{kHz}$. As the wavelength of the electromagnetic field is much longer than the electrode, the quasi-static approximation of the electrical field in the tissue is applied [26,42],

$$
\nabla \sigma_{t} \nabla V=0
$$

where $V$ is the electrical potential, and $\sigma_{\mathrm{t}}$ is the electrical conductivity of tissue.

Neumann boundary condition is used to describe the insulated boundary of tissue and the electrode:

$$
\nabla V=0
$$
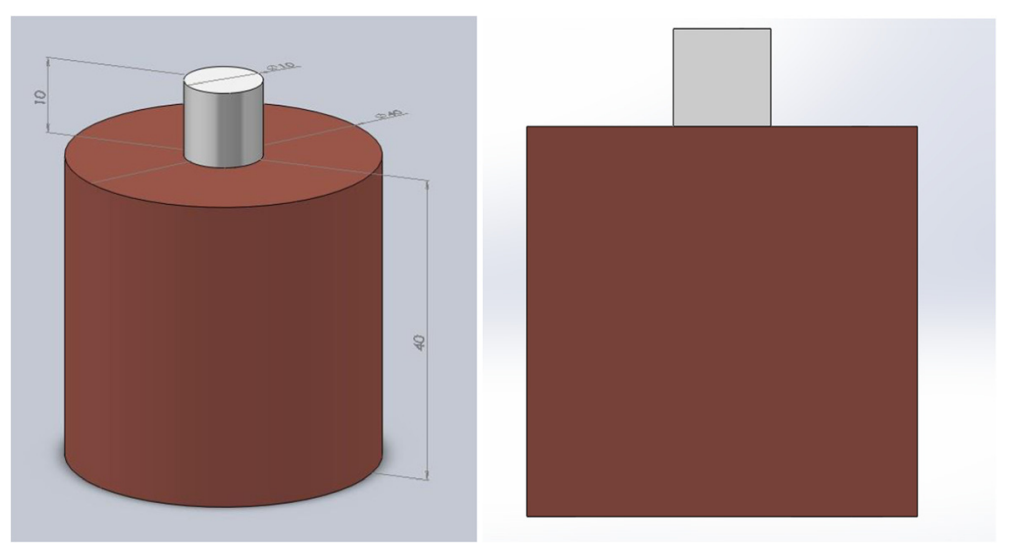

Figure 1 Schematic diagram of the eletrode and tissue. The gray cylinder represents the RF electrode, while the dark red cylinder represents the tissue. 
The absorption rate of RF energy in tissue, $Q_{S A R}\left(\mathrm{~W} / \mathrm{m}^{3}\right)$ is,

$$
Q_{S A R}=\sigma_{t}(\nabla V)^{2}
$$

Pennes' equation is used to describe the heat transfer inside the tissue [43],

$$
\rho_{t} c_{t} \frac{\partial T_{t}}{\partial t}=\nabla k_{t} \nabla T_{t}+\rho_{b} c_{b} w_{b}\left(T_{b}-T_{t}\right)+Q_{\text {meta }}+Q_{S A R}
$$

where $\rho_{t}, c_{t}, k_{t}$ stand for the density, heat capacity and thermal conductivity of the tissue; $T_{b}, w_{b}, \rho_{b}$ are the arterial blood temperature, blood perfusion rate, the density of blood; $Q_{\text {meta }}$ is the metabolic rate of tissue, and $Q_{S A R}$ is the specific absorption rate of tissue.

A natural convection boundary condition is used for the outer surface of the tissue cylinder which includes the upper surface excluding the contact surface between the electrode and tissue, the side surface, and the bottom surface of the modeled tissue cylinder, as shown in Figure 1,

$$
\left.k \nabla T\right|_{\text {boundary }}=h_{s}\left(T_{\text {air }}-T_{t}\right)
$$

where $h_{s}$ is the natural convection coefficient of air, and a value of $25 \mathrm{~W} / \mathrm{m}^{2} \mathrm{~K}$ is used.

The blood flow stops when the local temperature is higher than $50^{\circ} \mathrm{C}$ [44],

$$
w_{b}=\left\{\begin{array}{l}
w_{b 0} \quad T<50^{\circ} C \\
0 \quad T \geq 50^{\circ} C
\end{array}\right.
$$

And the metabolic rate of tissue is lineally dependent on temperature [45],

$$
Q_{\text {meta }}=\left\{\begin{array}{l}
Q_{\text {metao }}\left[1+10 \%\left(T-T_{0}\right)\right] \quad T \leq 50^{\circ} \mathrm{C} \\
0 \quad T>50^{\circ} \mathrm{C}
\end{array}\right.
$$

where $Q_{\text {metao }}$ is the metabolic rate in physiological state $\left(\mathrm{T}_{0}=37^{\circ} \mathrm{C}\right)$.

With temperature rising, ions and polar molecules in the tissue oscillate faster, which helps heat transfer and electromagnet field propagate. The physical phenomenon reflects in the changes of the thermal and electrical conductivity [46]. Their dependence on temperature has been studied by Bhattacharya [47] and Pop [48] experimentally. And it can be described by a linear function with an independent variable-temperature,

$$
\begin{aligned}
& k(T)=k_{0} *\left[1+0.3 \%\left(T_{t}-T_{0}\right)\right]^{*} 10^{-1} \\
& \sigma(T)=\sigma_{0}\left[1+0.016\left(T-T_{0}\right)\right]
\end{aligned}
$$

where $T_{0}$ is the reference temperature which is the initial temperature of tissue, usually the body temperature; $\sigma_{0}$ and $k_{0}$ are the electrical conductivity and thermal conductivity at $T_{0}$, separately.

As heating continues, temperature of the surface contacting with the electrode will reach the boiling point of water. According to Webster's experimental study [37], the excessive evaporation inside the tissue takes place between $100^{\circ} \mathrm{C}$ and $105^{\circ} \mathrm{C}$. Therefore, the boiling temperature of pure water under $1 \mathrm{~atm}, 100^{\circ} \mathrm{C}$, is used as the criterion for the occurrence of the evaporation inside the tissue. Thus according to energy conservation,

$$
Q_{\text {eva }}=-\left(Q_{S A R}+\nabla k_{t} \nabla T_{t}\right)
$$

where $Q_{e v a}$ is the energy absorbed by evaporation per unit volume of tissue. 
And the dynamic volume fraction of liquid water in tissue is,

$$
\frac{d m_{l}}{d t}=\frac{Q_{e v a}}{h_{f g}}+\nabla D_{l} \nabla m_{l}
$$

where $m_{l}$ is the mass of liquid water per unit volume of tissue, $h_{f g}$ is the latent heat of water, $Q_{\text {eva }}$ is the heat absorbed per unit volume of tissue by evaporation, and $D_{l}$ is the water diffusion coefficient, which exponentially increases with temperature according to Mill's [49] and Krynicki's study [49,50],

$$
D_{l}=12.5 * 10^{-9} \exp \left(-5.22 * 10^{-4}\right) \exp \left(\frac{-925 \exp \left(-2.6 * 10^{-4}\right)}{T_{t}-\left(95+2.61 * 10^{-2}\right)}\right) T_{t^{\frac{1}{2}}} \mathrm{~m}^{2} / \mathrm{s}
$$

The liquid water is considered as incompressible and the tissue volume assumed to be constant during the treatment. After evaporation, the space previously taken by the liquid water in tissue is filled with steam. The volume is occupied by a liquid-gas mixture. The liquid and gas fractions of water could be determined by:

$$
\begin{aligned}
& \phi_{w}=\frac{m_{l}}{m_{l 0}} \\
& \phi_{g}=1-\phi_{w}=1-\frac{m_{l}}{m_{l 0}}
\end{aligned}
$$

where $\phi_{g}$ and $\phi_{w}$ are the fractions of water in gas and liquid phase, $m_{l 0}$ is the initial mass of liquid water per unit volume of tissue.

The modified equation describing the electrical conductivity of the two-phase (liquid and gas) system is used [51]:

$$
\begin{gathered}
\frac{\sigma_{t}\left(T, m_{l}\right)}{\sigma(T)}=\frac{1+A B \phi_{g}}{1-B \psi \phi_{g}} \\
\psi=1+\left(\frac{1-\phi_{m}}{\phi_{m}^{2}}\right) \phi_{g}
\end{gathered}
$$

where $A$ is a constant that primarily depends on the shape and the orientation of dispersed particles, for randomly distributed bubbles in tissue, $\mathrm{A}$ is $1.5 ; B$ is a constant which represents the relative conductivity of the two components, and the value is $2 / 3$ for water and water vapor; $\phi_{m}$ is the maximum packing fraction of particles, and it is 0.637 for randomly packed sphere gas bubbles.

Thermal conductivity of the mixture is a linear function of water concentration [52]:

$$
k_{t}\left(m_{l}, T\right)=k(T) *\left(0.133+1.36 \frac{m_{l}}{m_{l 0}}\right)
$$

The electrical and thermal conductivities of the tissue depend both on temperature and the water content, the influence of both factors are assumed to be independent of 
each other, thus Eq. (15) is proposed to describe its dependence on both temperature and water content:

$$
\begin{aligned}
& \sigma_{t}\left(T, m_{l}\right)=\sigma_{0}\left[1+0.016\left(T-T_{0}\right)\right] \frac{1+A B \phi_{g}}{1-B \psi \phi_{g}} \\
& k_{t}\left(m_{l}, T\right)=4.19 *\left[1+0.3 \%\left(T_{t}-T_{0}\right)\right] * 10^{-1} *\left(0.133+1.36 \frac{m_{l}}{m_{l 0}}\right)
\end{aligned}
$$

The equations describing the electrical field, heat transfer and water evaporation Eq. (1)-Eq. (10) are solved by Comsol 4.2. The equations of thermal and electrical conductivities Eq. (11)-Eq. (15) are solved by Matlab7.0b, with the results input to Comsol to couple with the electrical and thermal equations at the same time. The choice of time step is determined by taking both computational convergence and efficiency into consideration. And $0.1 \mathrm{~s}$ and $0.01 \mathrm{~s}$ are chosen for the simulation process before and after the occurrence of evaporation respectively. Before the beginning of the evaporation (boiling), only Eq. (1) -Eq. (7) are needed to be solved. A time step of $0.1 \mathrm{~s}$ is small enough for convergence. When the evaporation takes place, Eq. (8)-Eq. (15) are evolved, as excessive changes taking place in a short time, thus after several trials, a time step of $0.001 \mathrm{~s}$ is chosen for this period.

\section{Results and discussion}

The parameters used in the model are listed in Table 1. The simulated transient temperature profiles, water content and the electrical field intensity inside tissue are shown in Figures 2, 3, 4 and 5. For comparison, the results obtained without considering the evaporation process are present in Figure 2a. They are obtained by deleting the water evaporation part in Eq. (8)-Eq. (14).

The temperature distribution at $\mathrm{t}=600 \mathrm{~s}$ is illustrated in Figure 2. It is found that the simulated highest temperature reaches $119.79^{\circ} \mathrm{C}$ if evaporation is not considered, while the highest temperature inside tissue is about $100.24^{\circ} \mathrm{C}$ when the evaporation process considered. If using $50^{\circ} \mathrm{C}$ as the critical temperature assessing cell viability, it can be found from the results that without considering the evaporation process, the 2-D lesion area will be $12.41 \%$ larger. Obviously, the model without considering evaporation overestimates the temperature profile in tissue and correspondently the tumor lesion size.

Table 1 Parameters used in the model

\begin{tabular}{llll}
\hline Parameter & Symbol & Value & Ref. \\
\hline Blood temperature & $\mathrm{T}_{\mathrm{b}}$ & $37^{\circ} \mathrm{C}$ & \\
Atmosphere temperature & $\mathrm{T}_{\text {air }}$ & $20^{\circ} \mathrm{C}$ & \\
Metabolic rate & $\mathrm{Q}_{\text {metao }}$ & $33800 \mathrm{~W} / \mathrm{m}^{3}$ & {$[53]$} \\
Latent of phase change & $\mathrm{h}_{\mathrm{fg}}$ & $2.26 \mathrm{E} \mathrm{J} / \mathrm{kg}$ & {$[53]$} \\
Constant of mixture & $\mathrm{A}$ & 1.5 & {$[51]$} \\
Constant of mixture & $\mathrm{B}$ & $-2 / 3$ & {$[51]$} \\
Constant of mixture & $\varphi_{m}$ & 0.637 & {$[51]$} \\
Electrical conductivity & $\sigma_{0}$ & $0.336 \mathrm{~S} / \mathrm{m}$ & {$[42,54]$} \\
Blood perfusion (volume rate of blood flow per unit volume of tissue) & $w_{b}$ & $0.008 \mathrm{~s}^{-1}$ & {$[42]$} \\
Original water fraction in the tissue (mass of water per unit volume of tissue) & $m_{10}$ & $778 \mathrm{~kg} / \mathrm{m}^{3}$ & {$[38]$} \\
Electrode voltage & $V$ & $35 \mathrm{~V}$ & \\
\hline
\end{tabular}




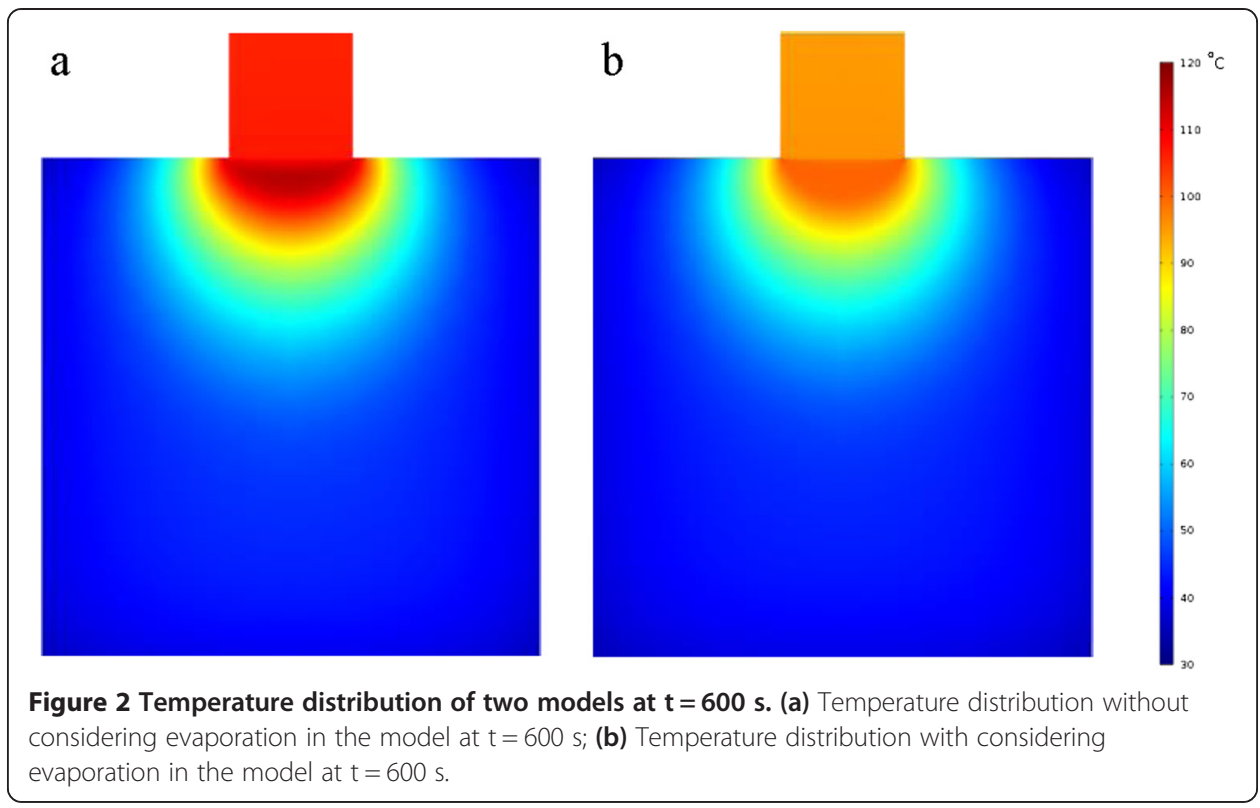

The transient temperature curves at the monitoring points are illustrated in Figure 3 . The points are at the center line of the tissue cylinder with $0 \mathrm{~mm}, 1 \mathrm{~mm}$, and $10 \mathrm{~mm}$ away from the contact surface. As seen from Figure 3, the temperatures at the first and the second monitor points which are closer to the contact surface $(0 \mathrm{~mm}, 1 \mathrm{~mm})$ keep rising before the temperature reaches a turning point, where the temperature starts to keep at a constant value $100^{\circ} \mathrm{C}$, with the adsorbed RF energy being exhausted by evaporation. The temperature at the third point which is $10 \mathrm{~mm}$ away from the contact surface keeps rising during the whole RF heating process, and no evaporation takes place at this point.

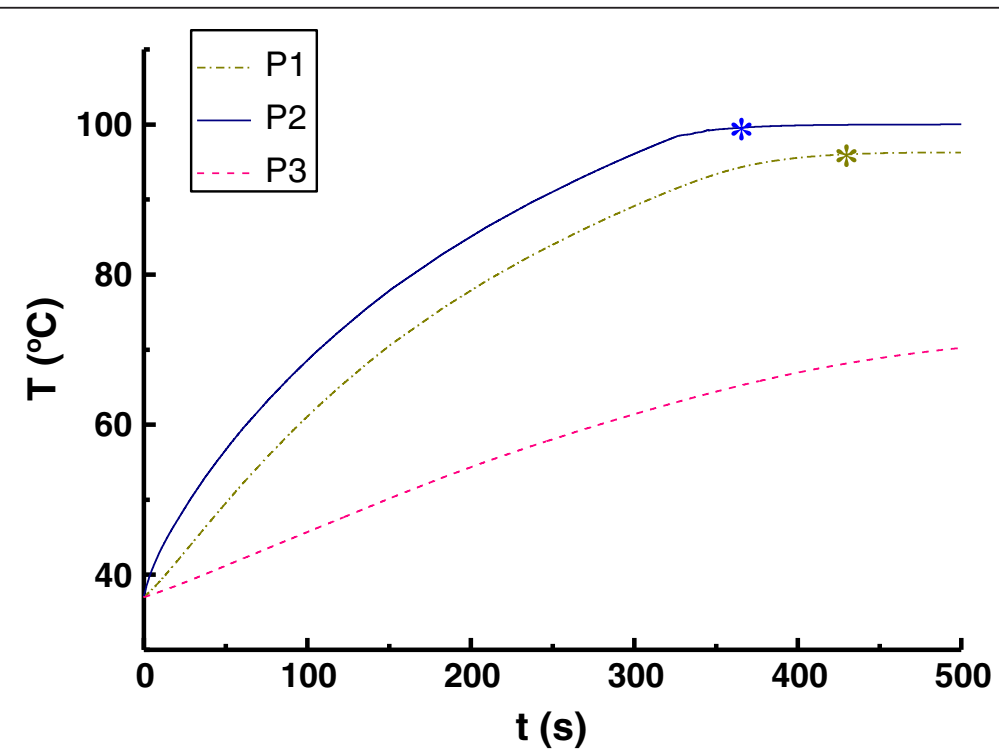

Figure 3 Transient temperatures at the monitoring points. P1, P2, P3 locate at the central axis of the tissue cylinder with $0 \mathrm{~mm}, 1 \mathrm{~mm}$ and $10 \mathrm{~mm}$ away from the contact surface of the electrode. 


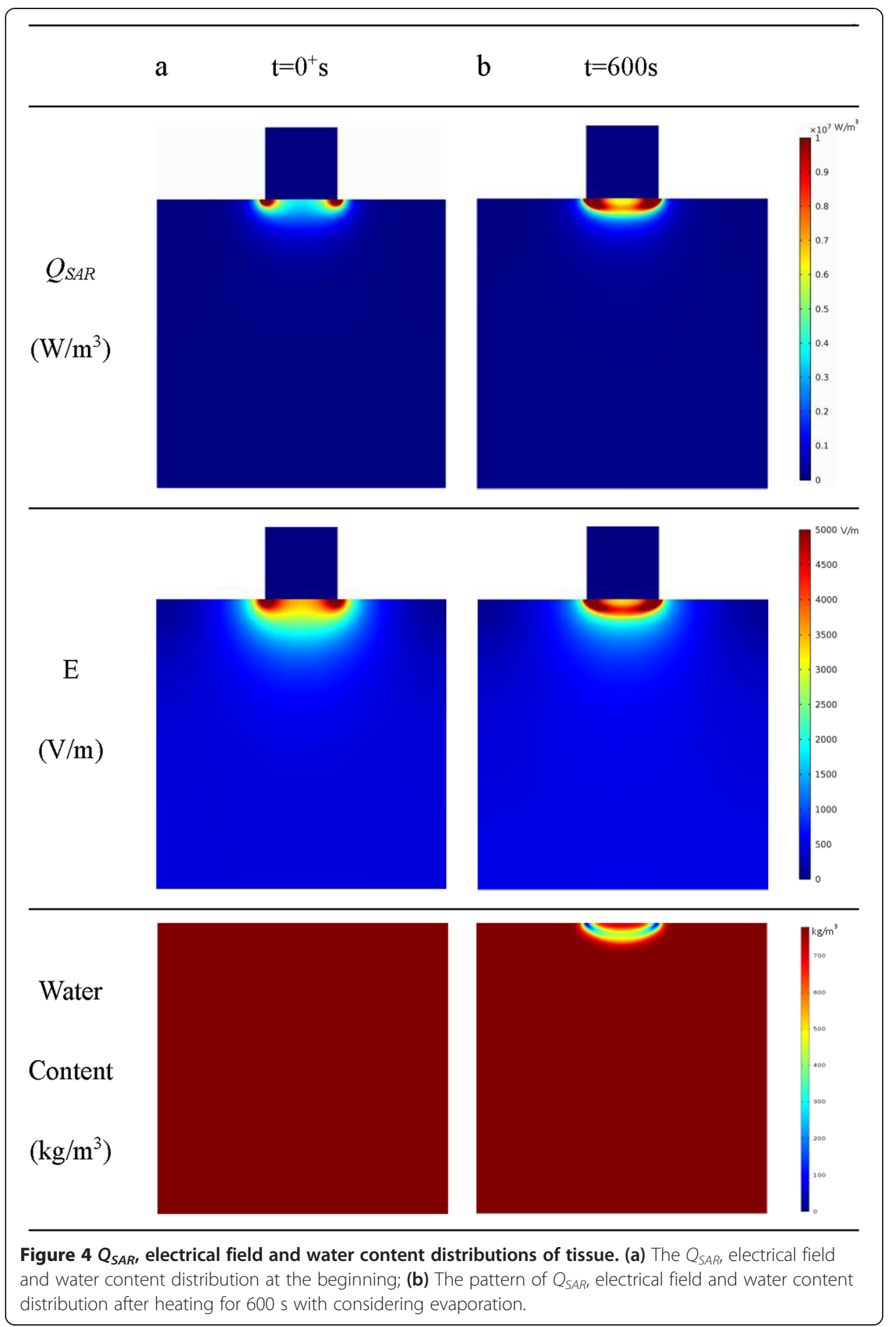

To find out how the evaporation process influences the transportation of RF energy, the electrical field $E$ and $Q_{S A R}$ of tissue are obtained, and results are illustrated in Figure 4. The field of the specific heat adsorption rate $Q_{S A R}$ and the electrical field intensity $E$ are established at the instant the RF treatment begins (Figure 4a). The largest electrical field intensity locates at the edge of the electrode contact surface, and the $E$-lines form semi-circle shapes with their centers at the edge of the electrode. After 


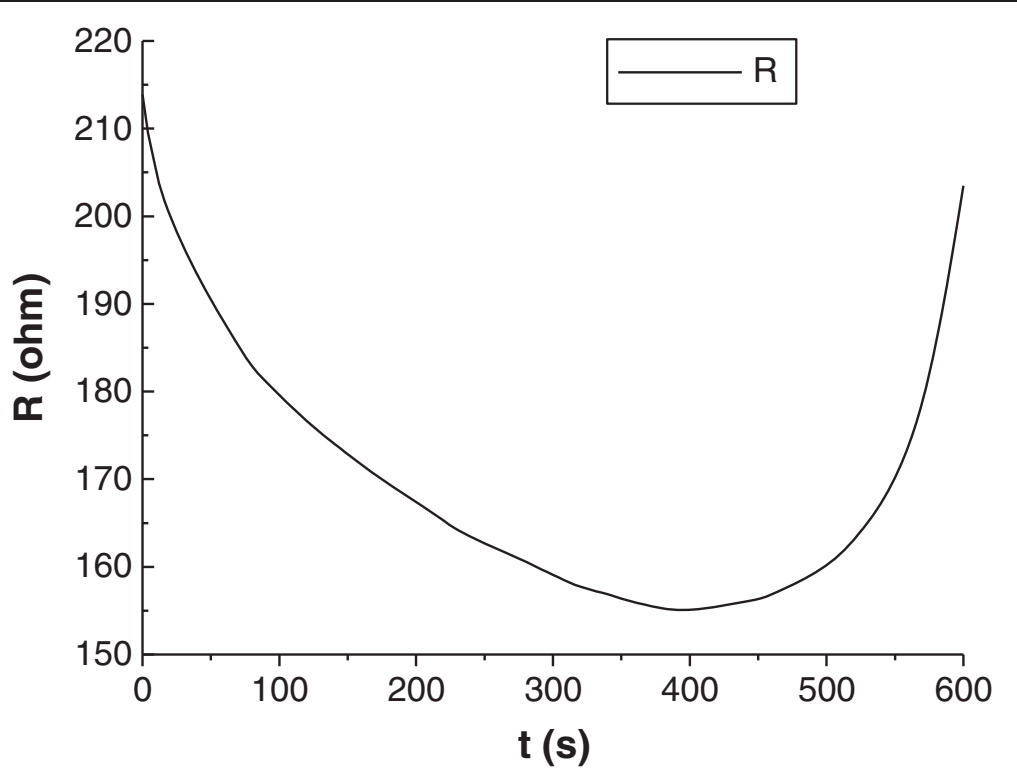

Figure 5 The tissue impedance during treatment. X-axis stand for the time of RF treatment, Y-axis stands for the tissue impedance.

being heated for $600 \mathrm{~s}$, though the locations with the largest value of $Q_{S A R}$ and the electrical field intensity are still at the edge of the electrode, the shapes of the $E$-lines are no longer semi circles (Figure $4 \mathrm{~b}$ ). Comparing with the distributions at the time point $t=0_{+}$, the electric field in the tissue after being heated for 10 minutes is more concentrated in the contacted area. And as shown in Figure 3, at this time point, excessive evaporation has taken place, it is the evaporation process that has reshaped the distribution of the $Q_{S A R}$ and electrical intensity $E$.

Also shown in Figure 4, the region with the largest $Q_{S A R}$ value is the place where the liquid water loses the most. With decrease of the water content in this region, the local electrical conductivity decreases, the water loss region forms a barrier for transportation of the electric currents in the radial direction. The trapped electrical field propagates more in the axial direction near the center line of the cylinder. This explains the unique shape of the $E$ lines shown in Figure 4b.

Tissue impedance is one of the most frequently used clinical criteria to decide when to adjust RF power or to stop the treatment [55]. The tissue impedance during the treatment is also calculated with results shown in Figure 5. It slowly decreases at the beginning of the treatment, and after reaches the lowest point (the turning point), it increases quickly. According to the simulated water content results, the water evaporation emerges at about $334 \mathrm{~s}$ after the treatment starts, while the reflection point of the impedance increasing from its former decreasing trend starts at $399 \mathrm{~s}$. There is a time interval of about $65 \mathrm{~s}$ between the occurrence of water evaporation and the inflection point of the impedance. This may due to the overwhelming influence of temperature on the tissue's electrical conductivity when the water content is not significantly decreased at the beginning of the heating.

According to the above simulation results, without adjusting the treatment protocol, there will form regions with serious water loss as barriers for RF energy delivery. However there is an interval between the occurrence of the evaporation and the beginning of the 
impedance increase. If at a certain time after the evaporation starts, terminating the heating allowing some time for the liquid water in the adjacent region to rehydrate the region may help enlarge the coagulation depth of the treatment. To find out its effectiveness, a heating process as illustrated in Figure 6a is studied. The first RF heating ends at $656 \mathrm{~s}$ as the impedance exceeds $500 \mathrm{ohm}$. Then a $5 \mathrm{~min}$ of natural cooling of tissue is allowed before restarting the RF heating. The second heating lasts for $344 \mathrm{~s}$ until the impedance exceeds $500 \mathrm{ohm}$ again. During the natural cooling process, it can be seen that the tissue impedance first drops dramatically, and then increases slowly. The change of the impedance is clearly related to the water content inside the tissue. The temperature distribution at these time points $(t=656 \mathrm{~s}, \mathrm{t}=956 \mathrm{~s}$, $\mathrm{t}=1300 \mathrm{~s})$ are given in Figure 6b-d. Unexpected, after the second heating $(\mathrm{t}=1300 \mathrm{~s})$, the heated region whose temperature is greater than $50^{\circ} \mathrm{C}$ is $28.5 \%$ less than that resulted from the first heating. This result suggests that by just waiting for the water to flow back to the dehydrated region is not an effective way improving the treatment outcome. During the intermittent thawing process when water flows back (about $64.3 \%$ rehydrated after 5 min, results not shown), the local temperature also drops (Figure 6d). The second heating only increases the temperature of the same region to the previous point and fails

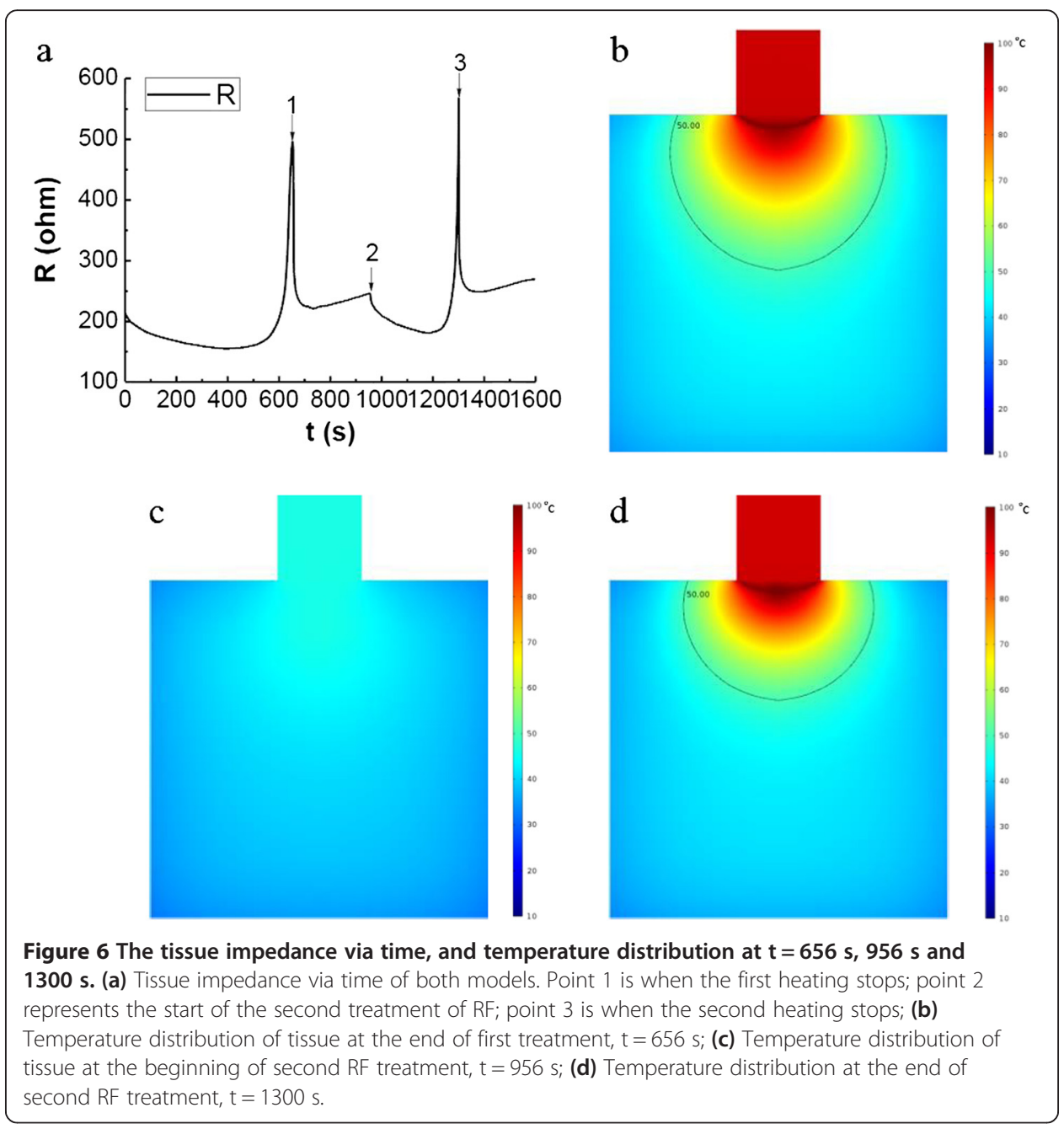


to further propagate before the gas gap forms again and significantly increases the impedance. Continuously hydrating the water loss region of the tissue without decreasing the local temperature shall be more effective, adding hot sterile saline is an option if the process is well controlled.

To avoid local carbonization due to dehydration, electrodes with cooling agent flowing inside have been used [56,57]. Circulation of the cooling agent dissipates heat from the electrode wall and thus decreases the temperature in the adjacent region, which helps reduce local water evaporation. It has been proved effective in improving thermal ablation outcome of large tumor. To help optimize the treatment protocols, outcome of three different cooling strategies are predicted using the proposed model. The convective coefficient between the electrode wall and the circulating fluid $h_{\mathrm{e}}$ is assumed to be $25 \mathrm{~W} / \mathrm{m}^{2} \mathrm{~K}, 100 \mathrm{~W} / \mathrm{m}^{2}$ and infinity. The temperature of the cooling agent is $20^{\circ} \mathrm{C}$.

The temperature distribution and water content in the tissue during the treatment with these conditions are calculated and illustrated in Figure 7. It is found that during the treatment with the cooled-tip electrodes, there are certain locations inside the tissue whose temperature would reach the boiling point for all the cooling conditions studied, and under the first two conditions (with limited convection coefficient, there would form a complete enclosed gas gap in the tissue (shown in Figure 7a and b). This completely blocks further energy transmission of RF. It takes $205 \mathrm{~s}$ and $476.5 \mathrm{~s}$ for the complete gas gap to form for the first two cooling conditions, respectively. While for the infinite convective coefficient, that is, the temperature of the electrode wall is maintained at a constant value, thermal equilibrium achieves at $1400 \mathrm{~s}$. Circulation of the cooling agents inside the electrode not only extends the therapy time but also the therapy area. The fraction of the tissue area with temperature higher than $50^{\circ} \mathrm{C}$ divided by the total tissue area in the $2 \mathrm{D}$-section are $22.0 \%, 41.5 \%$ and $33.9 \%$ respectively under the three conditions. It is the largest for the process with moderate convection coefficient $\left(100 \mathrm{~W} / \mathrm{m}^{2} \mathrm{~K}\right)$ of the cooling agent.

Another finding is that the flowing condition of the cooling fluids also alters the pattern of water loss. For the flow with a lower convection coefficient, the water loss first occurs at the edge of contact surface. While for the medium and extremely high convection coefficients, the water loss starts from the center of tissue at about $2.5 \mathrm{~mm}$ below the contact surface. The results suggest that the treatment region can be shaped by controlling the flowing conditions inside the electrode.

Further investigation of the transient temperature distribution during the treatment (Figure 8) has found that for some time after evaporation takes place, there is a decrease of the local temperature. The monitoring point in Figure $8 \mathrm{a}$ is the center of the contact surface. At the time when the temperature at this point starts to decrease, the gas vapor may have formed a barrier for the electrical field and also decreases the thermal conduction, while at the same time, the cooling agent continuously circulates, and it lowers the local temperature of tissue.

From Figure 8b, it can be found that impedance decreases slightly before the vapor point, and increases suddenly while gas forms a gap. Comparing Figure 8a and b, the turning point achieves at $125 \mathrm{~s}$ under the low convection coefficient and $195 \mathrm{~s}$ under the medium convection coefficient; and the impedance exceeds $500 \mathrm{ohm}$ at $204 \mathrm{~s}$ under the low convection coefficient and $476 \mathrm{~s}$ under the medium convection coefficient. The larger the convection coefficient is, the longer the treatment time required. 


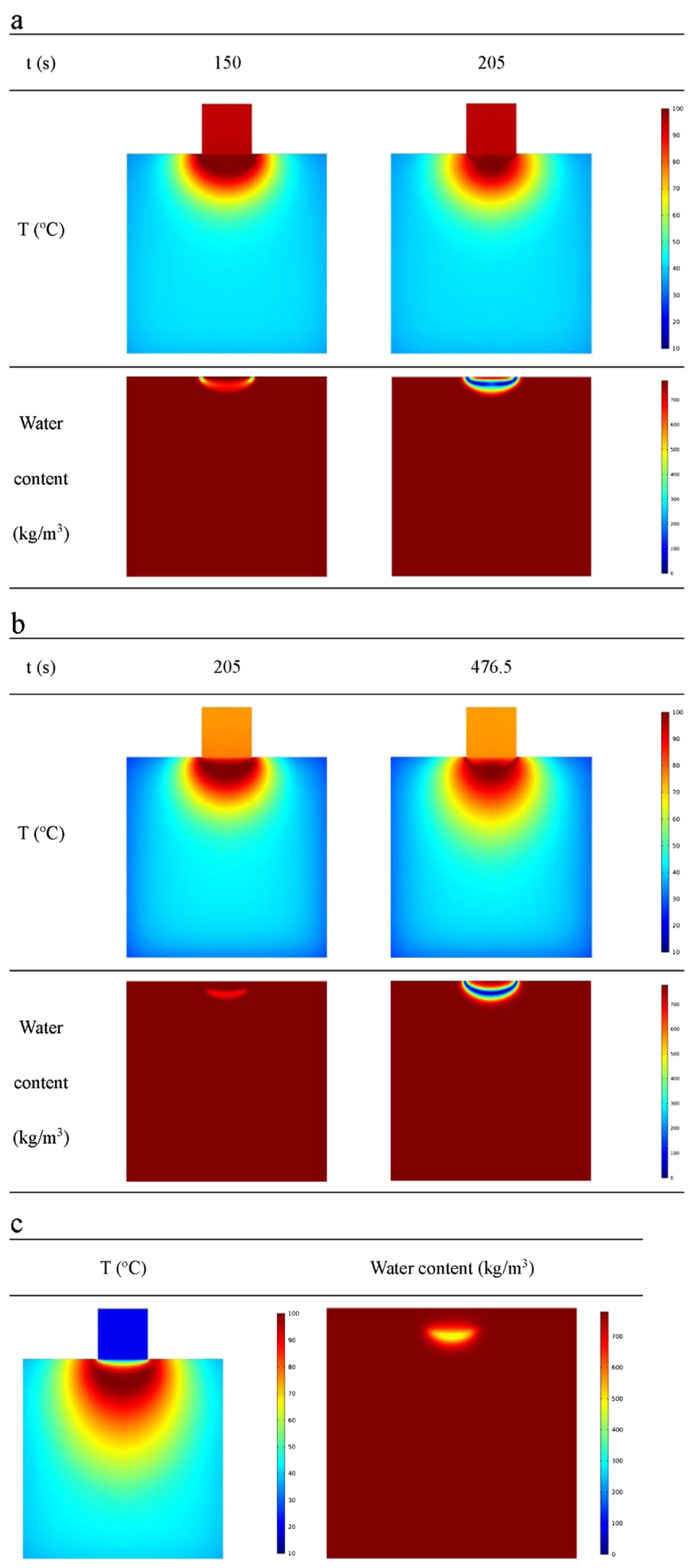

Figure 7 (See legend on next page.) 
(See figure on previous page.)

Figure 7 Temperature and water content distribution at different cooling conditions. (a)

Temperature and water content distributions under low convection coefficient $\left(h=25 \mathrm{~W} / \mathrm{m}^{2} \mathrm{~K}\right)$ at $150 \mathrm{~s}$ and

$205 \mathrm{~s}$. (b) Temperature and water content distributions under medium convection coefficient at $205 \mathrm{~s}$

and $476.5 \mathrm{~s} \mathrm{~h}=100 \mathrm{~W} / \mathrm{m}^{2}$. (c) Temperature and water content distribution under constant temperature

$\left(\mathrm{T}=20^{\circ} \mathrm{C}\right)$ at $1400 \mathrm{~s}$.

One interesting phenomenon observed is that, at the end of treatment, the impedance during the treatment with the medium convection coefficient increases more rapidly than that under a lower convection coefficient. As seen from Figure 8b, it costs $10.6 \mathrm{~s}$ for the impedance increasing from $115 \mathrm{ohm}$ to $500 \mathrm{ohm}$ under a larger convective coefficient, while it costs $25.6 \mathrm{~s}$ under the other condition. The result suggests that when cooled-tip electrode is applied, monitoring the rising of the impedance is necessary.

Besides, though the larger the convection coefficient, the longer the treatment time is, with further increase of the convection coefficient, a lot more heat is dissipated by the convection. When the cooling process exceeds the heating effect of the RF, the ablated size would decrease. There would be an optimal flow conditions inside the probe for a certain shaped ablation requirement. The model presented in this paper is expected to be useful in the treatment planning.

In devices developed in $[41,58,59]$, low temperature nitrogen is used as cooling agent inside the treatment probe. As the nitrogen has a small thermal capacity, the temperature of the flow also changes, by coupling with the flow and heat transfer of the fluid, the model could be used for its better planning.

However, in the model, free diffusion of water is used, and the effect of the tissue structure on the diffusion would result in slower liquid water diffusion, and correspondently an earlier forming of a complete gas region. The pressure difference in tissue is also neglected. With further understanding of gas and water transport during the evaporation, the model will be more accurate to predict temperature above $100^{\circ} \mathrm{C}$ and dynamical impedance variation. With the patient information of tumor geometry and vessel distribution by imaging technique, it is possible to predict temperate distribution by RFA, and to optimize the placement of electrode.
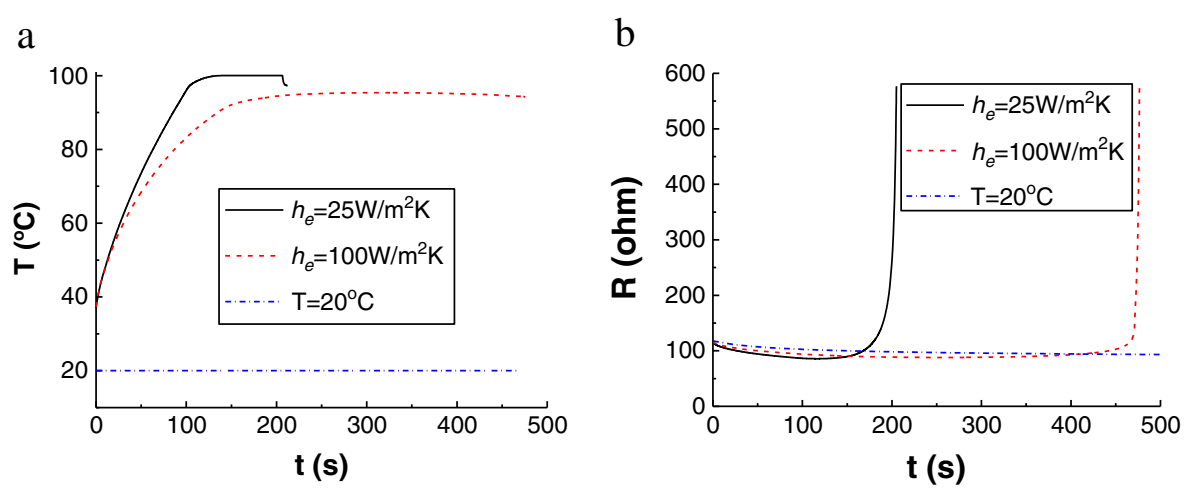

Figure 8 Transient temperature and impedance via time. (a) Transient temperature and (b) Transient impedance changes at the monitoring point under different treatment conditions. 


\section{Conclusions}

In this study, a model incorporating evaporation, water diffusion and its influence on thermal and electrical conductivity has been developed to simulate the RF treatment. The distribution of the temperature, electrical field, $Q_{S A R}$ and water content in the tissue under different treatment conditions have been obtained numerically. The results show that the evaporation will not only maintain the highest temperature of tissue at $100^{\circ} \mathrm{C}$, but also influence the distribution of the electrical field and the $Q_{S A R}$. A time lag between the emerging of the evaporation and increase of the tissue impedance is found, which is consistent with others' experiment findings.

It is also predicted that terminating the heating for a while to allow time for liquid water to flow back to the dehydrated region during the treatment would not enlarge the coagulation zone. The numerical results also confirm the advantage of the cooled-tip electrode. Increase in the convective coefficient of the circulating cooling agent inside the electrode would extend the treatment time, reduce the occurrence of the local evaporation and reshape the treated region, but not necessarily enlarge the size of the ablated region. Water loss emerges at different region of tissue under different convection condition. And the tissue impedance would increase more sharply before charring occurs under the medium convection condition. Thus, it is necessary to monitor the increase rate of impedance during the treatment.

Abbreviations
RFA: Radiofrequency ablation; RF: Radiofrequency; SAR: Specific absorption rate.

Competing interests

The authors declare that they have no competing interests.

Authors' contributions

QZ developed the mathematical model, carried out numerical simulations, and drafted the manuscript. YS participated in code debug and manuscript revision; AZ and LX instructed model development, results interpretation and manuscript writing and revision. All authors read and approved the final manuscript.

\section{Acknowledgements}

This work has been supported by Shanghai Science and Technology Commission of Shanghai Municipality (11DZ2211000), National Natural Science Foundation of China (NSFC51076095).

\section{Author details}

${ }^{1}$ State Key Laboratory of Oncogenes and Related Genes, School of Biomedical Engineering, Med-X Research Institute, Shanghai Jiao Tong University, Shanghai, China. ${ }^{2}$ National-Regional Key Technology Engineering Laboratory for Medical Ultrasound, Department of Biomedical Engineering, School of Medicine, Shenzhen University, Shenzhen 518060, China.

Received: 10 September 2013 Accepted: 26 November 2013

Published: 10 December 2013

\section{References}

1. Ahmed M, Goldberg S: Principles of radiofrequency ablation. In Interventional Oncology. Edited by Mueller P, Adam A. New York: Springer; 2012:23-37.

2. Calderwood SK: Hyperthermia, the tumor microenvironment and immunity. In Tumor Ablation. Volume 5. Edited by Keisari Y. Netherlands: Springer; 2013:29-37. The Tumor Microenvironment.

3. Haines DE, Verow AF: Observations on electrode-tissue interface temperature and effect on electrical impedance during radiofrequency ablation of ventricular myocardium. Circulation 1990, 82:1034-1038.

4. Trujillo M, Alba J, Berjano E: Relationship between roll-off occurrence and spatial distribution of dehydrated tissue during RF ablation with cooled electrodes. Int J Hyperther 2012, 28:62-68.

5. Nagtegaal ID, Quirke $P$ : What is the role for the circumferential margin in the modern treatment of rectal cancer? J Clin Oncol 2008, 26:303-312.

6. Hines-Peralta A, Hollander CY, Solazzo S, Horkan C, Liu ZJ, Goldberg SN: Hybrid radiofrequency and cryoablation device: preliminary results in an animal model. J Vasc Interv Radiol 2004, 15:1111-1120.

7. Ring ME, Huang SK, Gorman G, Graham AR: Determinants of impedance rise during catheter ablation of bovine myocardium with radiofrequency energy. Pacing Clin Electrophysiol 1989, 12:1502-1513. 
8. Stein T: Untersuchungen zur Dosimetrie der hochfrequenzstrominduzierten interstitiellen thermotherapie in bipolarer technik. Ecomed Press 2000.

9. Ni Y, Mulier S, Miao Y, Michel L, Marchal G: A review of the general aspects of radiofrequency ablation. Abdom imagingl 2005, 30:381-400.

10. Zhang XT, Zhu SA, He B: Imaging electric properties of biological tissues by RF field mapping in MRI. IEEE T Med Imaging 2010, 29:474-481.

11. Ahmed M, Liu Z, Humphries S, Goldberg SN: Computer modeling of the combined effects of perfusion, electrical conductivity, and thermal conductivity on tissue heating patterns in radiofrequency tumor ablation. Int J Hyperther 2008, 24:577-588.

12. Haemmerich D, Wright AW, Mahvi DM, Lee FT Jr, Webster JG: Hepatic bipolar radiofrequency ablation creates coagulation zones close to blood vessels: a finite element study. Med Biol Eng Comput 2003, 41:317-323.

13. Crocetti $L$, de Baere $T$, Lencioni R: Quality improvement guidelines for radiofrequency ablation of liver tumours. Cardiovasc Inter Rad 2010, 33:11-17.

14. Solbiati L, Goldberg SN, lerace T, Livraghi T, Meloni F, Dellanoce M, Sironi S, Gazelle GS: Hepatic metastases: percutaneous radio-frequency ablation with cooled-tip electrodes. Radiology 1997, 205:367-373.

15. Meijerink MR, van den Tol P, van Tilborg AAJM, van Waesberghe JHTM, Meijer S, van Kuijk C: Radiofrequency ablation of large size liver tumours using novel plan-parallel expandable bipolar electrodes: initial clinical experience. Eur J Radiol 2011, 77:167-171.

16. Lee J, Lee JM, Yoon JH, Lee JY, Kim SH, Lee JE, Han JK, Choi BI: Percutaneous radiofrequency ablation with multiple electrodes for medium-sized hepatocellular carcinomas. Korean J Radiol 2012, 13:34-43.

17. Kettenbach J, Kostler W, Rucklinger E, Gustorff B, Hupfl M, Wolf F, Peer K, Weigner M, Lammer J, Muller W, Goldberg SN: Percutaneous saline-enhanced radiofrequency ablation of unresectable hepatic tumors: initial experience in 26 patients. AJR Am J Roentgenol 2003, 180:1537-1545.

18. Kim JH, Kim PN, Won HJ, Shin YM: Percutaneous radiofrequency ablation using internally cooled Wet electrodes for the treatment of hepatocellular carcinoma. Am J Roentgenol 2012, 198:471-476.

19. Watanabe I, Masaki R, Min N, Oshikawa N, Okubo K, Sugimura H, Kojima T, Saito S, Ozawa Y, Kanmatsuse K: Cooled-tip ablation results in increased radiofrequency power delivery and lesion size in the canine heart: importance of catheter-tip temperature monitoring for prevention of popping and impedance rise. I Interv Card Electr 2002, 6:9-16.

20. Hong K, Georgiades C: Radiofrequency ablation: mechanism of action and devices. J Vasc Interv Radiol 2010, 21: S179-S186.

21. Mah YH, Ng KH, Abdullah BJJ, Kwek KH, Wong JHD: Ex vivo experiment of bovine liver using cool-tip (TM) radiofrequency ablation system. In World Congress on Medical Physics and Biomedical Engineering, Vol 25, Pt 6. Volume 25. Edited by Dossel O, Schlegel WC. New York: Springer; 2009:209-212. IFMBE Proceedings].

22. Berjano EJ: Theoretical modeling for radiofrequency ablation: state-of-the-art and challenges for the future. Biomed Eng Online 2006, 5:24-40.

23. Haemmerich D, Tungjitkusolmun S, Staelin ST, Lee FT, Mahvi DM, Webster JG: Finite-element analysis of hepatic multiple probe radio-frequency ablation. IEEE T Bio-Med Eng 2002, 49:836-842.

24. Laeseke PF, Sampson LA, Haemmerich D, Brace CL, Fine JP, Frey TM, Winter TC, Lee FT: Multiple-electrode radiofrequency ablation: simultaneous production of separate zones of coagulation in an in vivo porcine liver model. J Vasc Interv Radiol 2005, 16:1727-1735.

25. Boss A, Clasen S, Kuczyk M, Schick F, Pereira PL: Image-guided radiofrequency ablation of renal cell carcinoma. Eur Radiol 2007, 17:725-733.

26. Chang IA: Considerations for thermal injury analysis for RF ablation devices. Open Biomed Eng J 2010, 4:3-12.

27. Liu Z, Ahmed M, Sabir A, Humphries S, Goldberg SN: Computer modeling of the effect of perfusion on heating patterns in radiofrequency tumor ablation. Int I Hyperther 2007, 23:49-58.

28. Lobo SM, Liu ZJ, Yu NC, Humphries S, Ahmed M, Cosman ER, Lenkinski RE, Goldberg W, Goldberg SN: RF tumour ablation: computer simulation and mathematical modelling of the effects of electrical and thermal conductivity. Int J Hyperther 2005, 21:199-213.

29. Suarez AG, Hornero F, Berjano EJ: Mathematical modeling of epicardial RF ablation of atrial tissue with overlying epicardial fat. Open Biomed Eng J 2010, 4:47-55.

30. Elwassif MM, Kong $\mathrm{Q}$, Vazquez M, Bikson M: Bio-heat transfer model of deep brain stimulation-induced temperature changes. J Neural Eng 2006, 3:306-315.

31. Consiglieri L: Continuum models for the cooling effect of blood flow on thermal ablation techniques. Int J Thermophys 2012, 33:864-884.

32. Ahmed M, Liu Z, Afzal KS, Weeks D, Lobo SM, Kruskal JB, Lenkinski RE, Goldberg SN: Radiofrequency ablation: effect of surrounding tissue composition on coagulation necrosis in a canine tumor model. Radiology 2004, 230:761-767.

33. Tungjitkusolmun S, Woo EJ, Cao H, Tsai JZ, Vorperian VR, Webster JG: Thermal-electrical finite element modelling for radio frequency cardiac ablation: effects of changes in myocardial properties. Med Biol Eng Comput 2000, 38:562-568.

34. Ekstrand V, Wiksell H, Schultz I, Sandstedt B, Rotstein S, Eriksson A: Influence of electrical and thermal properties on RF ablation of breast cancer: is the tumour preferentially heated? Biomed Eng Online 2005, 4:41.

35. dos Santos I, Haemmerich D, da Silva Pinheiro C, da Rocha AF: Effect of variable heat transfer coefficient on tissue temperature next to a large vessel during radiofrequency tumor ablation. Biomed Eng Online 2008, 7:21.

36. Ai HM, Wu SC, Gao HJ, Zhao L, Yang CL, Zeng Y: Temperature distribution analysis of tissue water vaporization during microwave ablation: Experiments and simulations. Int J Hyperther 2012, 28:674-685.

37. Yang D, Converse MC, Mahvi DM, Webster JG: Expanding the bioheat equation to include tissue internal water evaporation during heating. IEEE Trans Biomed Eng 2007, 54:1382-1388,

38. Yang D, Converse MC, Mahvi DM, Webster JG: Measurement and analysis of tissue temperature during microwave liver ablation. IEEE Trans Biomed Eng 2007, 54:150-155. 
39. Pätz T, Kröger T, Preusser T: Simulation of radiofrequency ablation including water evaporation, September 7-12, 2009, Munich, Germany. Volume 25/4. In World Congress on Medical Physics and Biomedical Engineering. Edited by Dössel O, Schlegel W. Berlin Heidelberg: Springer; 2010:1287-1290. IFMBE Proceedings.

40. Patz T, Preusser T: Composite finite elements for a phase change model. Siam J Sci Comput 2012, 34:B672-B691.

41. Cai ZH, Song MY, Zhang AL, Sun JQ, Xu LXM: Numerical simulation of a new probe for the alternate cooling and heating of a subcutaneous mouse tumor model. Numer Heat Tr a-Appl 2013, 63:534-548.

42. Tungjitkusolmun S, Staelin ST, Haemmerich D, Tsai JZ, Cao H, Webster JG, Lee FT, Mahvi DM, Vorperian VR: Three-dimensional finite-element analyses for radio-frequency hepatic tumor ablation. IEEE T Bio-Med Eng 2002, 49:3-9.

43. Pennes HH: Analysis of tissue and arterial blood temperatures in the resting human forearm (Reprinted from Journal of Applied Physiology, vol 1, pg 93-122, 1948). J Appl Physiol 1998, 85:5-34.

44. Chen $X$, Saidel GM: Mathematical modeling of thermal ablation in tissue surrounding a large vessel. J Biomech Eng 2009, 131:011001.

45. Hand JW, Ledda JL, Evans TS: Temperature distribution in tissues subjected to local hyperthermia by RF induction heating. Brit J Cancer 1982, 5:31-35.

46. Gabriel S, Lau RW, Gabriel C: The dielectric properties of biological tissues: II. Measurements in the frequency range $10 \mathrm{~Hz}$ to $20 \mathrm{GHz}$. Phys Med Biol 1996, 41:2251-2269.

47. Bhattacharya A, Mahajan RL: Temperature dependence of thermal conductivity of biological tissues. Physiol Meas 2003, 24:769-783.

48. Pop M, Molckovsky A, Chin L, Kolios MC, Jewett MAS, Sherar M: Changes in dielectric properties at $460 \mathrm{kHz}$ of kidney and fat during heating: importance for radio-frequency thermal therapy. Phys Med Biol 2003, 48:2509-2525.

49. Mills R: Self-diffusion in normal and heavy water in the range 1-45.deg. J Phys Chem 1973, 77:685-688.

50. Krynicki K, Green CD, Sawyer DW: Pressure and temperature dependence of self-diffusion in water. Faraday Discuss Chem Soc 1978, 66:199-208.

51. Nielsen LE: The thermal and electrical conductivity of two-phase systems. Ind Eng Chem Fundam 1974, 13:17-20.

52. Jacques SL, Prahl SA: Modeling optical and thermal distributions in tissue during laser irradiation. Lasers Surg Med 1987, 6:494-503.

53. Keangin $P$, Rattanadecho $P$, Wessapan $T$ : An analysis of heat transfer in liver tissue during microwave ablation using single and double slot antenna. Int Commun Heat Mass 2011, 38:757-766

54. Miklavčič D, Pavšelj N, Hart FX: Electric properties of tissues. In Wiley Encyclopedia of Biomedical Engineering. Edited by Akay M. New York: Wiley; 2006:3578-3589.

55. lida H, Aihara T, Ikuta S, Yamanaka N: Effectiveness of impedance monitoring during radiofrequency ablation for predicting popping. World J Gastroentero 2012, 18:5870-5878.

56. Tateishi R, Shiina S, Teratani T, Obi S, Sato S, Koike Y, Fujishima T, Yoshida H, Kawabe T, Omata M: Percutaneous radiofrequency ablation for hepatocellular carcinoma - An analysis of 1000 cases. Cancer 2005, 103:1201-1209.

57. Miao Y, Ni YC, Bosmans H, Yu J, Vaninbroukx J, Dymarkowski S, Zhang H, Marchal G: Radiofrequency ablation for eradication of renal tumor in a rabbit model by using a cooled-tip electrode technique. Ann Surg Oncol 2001, 8:651-657.

58. Sun J, Zhang A, Xu LX: Evaluation of alternate cooling and heating for tumor treatment. Int J Heat Mass Tran $2008,51: 5478-5485$.

59. Chen C, Zhang A, Cai Z, Sun J, Xu LX: Design of microprobe for accurate thermal treatment of tumor. Cryo Letters $2011,32: 275-286$

doi:10.1186/1475-925X-12-127

Cite this article as: Zhu et al: Numerical study of the influence of water evaporation on radiofrequency ablation. BioMedical Engineering OnLine 2013 12:127.

\section{Submit your next manuscript to BioMed Central and take full advantage of:}

- Convenient online submission

- Thorough peer review

- No space constraints or color figure charges

- Immediate publication on acceptance

- Inclusion in PubMed, CAS, Scopus and Google Scholar

- Research which is freely available for redistribution

Submit your manuscript at www.biomedcentral.com/submit 